\title{
Investigating Indonesian Pre-Service Teachers' Speaking Anxiety in EFL Classroom
}

\author{
Ahmad Syafi'i \\ STKIP Al Hikmah Surabaya, email: ahmadsyafii20@gmail.com
}

\begin{abstract}
The objective of this research are to investigate pre-service teachers' speaking anxiety in EFL classroom. The subject of this research was 40 pre-service teachers of STKIP Al Hikmah Surabaya Indonesia. The research design of this study is descriptive qualitative research. The main single instrument used in this research was questionnaire. The questionnaire used in the form of Likert scale which was adopted and developed from Horwitz. In this study, questionnaire was applied as the single instruments. In analyzing data, an interactive data analysis model proposed by Miles M.B and Huberman A.M (1984) was used. The result of the study were: (1) All pre service teachers experienced speaking anxiety in EFL classroom. (2) There are five major areas of speaking anxiety experienced by pre service teachers in EFL classroom namely fear of interaction, fear of perception of others, low self esteem and lack of confidence, language proficiency, and error correction or fear of negative corection.
\end{abstract}

Key words: Indonesian pre-service teachers, speaking anxiety, EFL classroom

\section{INTRODUCTION}

Speaking ability is oftenly perceived difficult to learn because it is closely related to either words production or conveying messages. In other words, speaking well requires the use of comprehensible series of words It is in line with Toth (2010) who said that speaking in English is a tense thing for students, that because they feel that they are afraid of making mistakes related to grammar and the lack of vocabulary in English to facilitate their speaking activities. Therefore, speaking ability also require certain strategies particularly to avoid miscommunication or interference in communication

Based on the observation conducted to 40 pre-service teachers who become the subject of this study, it is revealed that they still experienced nervousness and afraid when they are required to speak in EFL classroom. It is simply concluded that they still have serious problem particularly in speaking English. Feeling nervous and afraid when students speak is a form of students speaking anxiety. It is in line with Spielberger ac cited in Brown (2004) who clearly stated that anxiety is a subjective feeling of tension, 
fear, anxiety. Furthermore, anxiety is closely associated with the excitement of the autonomic nervous system. Therefore, anxiety plays such a very significant influence on both the success of student's communication and improving students' speaking English skills. As a result, if anxiety felt by students is not well treated, it will presumably adversely affect to students. However, if anxiety can be succesfully eliminated, it will greatly assist students to grow their confidence.

Speaking anxiety is a common phenomenon most language learners experienced particulary in EFL context. Though the level of anxiety could be various among learners. Students usually become anxious when they are not native speakers of a particular language but are required to study or use the language Chowduri (2014).

Several factors that cause students' anxiety expressed by Shu-Feng Tseng (2012) that are:

\section{Self-perception / self-concept / self-esteem}

The term self-perception has been used in the same sense as self-concept and has been found to be very related to language anxiety. Shu Feng Tseng also said that "The more I think about self-esteem, the more impressed I am about the impact". This is what causes anxiety to many people. People with low selfperception worry about what other people think. Christina (2015) also said that student's opinion mostly influence their speaking anxiety. This means that people with high self-perception have low levels of anxiety and those with low self-perception have high levels of anxiety. Daradjat (in Tiara, 2010) said that one of the causes of person experience anxiety is because of feeling helpless, so they feel unable to do something that can be done by others. They feel lack of confidence in their abilities that cause speaking anxiety.

2. Social status and identity

Students will sometimes lack confidence when they talk to someone with a higher status. They were very careful to speak until their conversation became uncontrolled because they thought of using perfect language. Some students also fear losing their identity if they learn another language. Devito (1995) explains that one of the factors influencing public speaking anxiety is lower status. The speaker is easily experiencing anxiety if he knows that the individual he is speaking to has a higher status than him 


\section{Classroom environment}

Students' views of class are places where their mistakes are noticed and their shortcomings are shown. Students feel more anxious and stressed in a classroom environment that follows traditional behaviorist learning theory or using strict classroom style. Conversely, students feel less anxious and stressed in a classroom environment that follows constructivist learning theory. This emphasizes collaborative activities by forming learning communities including teachers and students.

4. Presentation in the classroom.

Giving short presentations in class is reported to cause high anxiety, which makes the classroom environment more formal and stressful for students. Students assume that speaking in front of the whole class or in public cause anxiety for most students. They, sometimes, think that maybe the audiences don't understand what is my speech about, I might say the wrong words, or I might give a wrong explanation about the presentation material etc. Presenting certain topics in front of the class can make a different atmosphere and it is very likely to create speaking anxiety for the speaker.

5. Afraid of making mistakes and fears about evaluating others.

Jones (2004) states that students feel scared and even panic for fear of making mistakes in front of other people. That makes them unable to communicate properly. This will explain why anxious students tend to avoid class participation, because they are not sure what they say or lose trust when giving answers to questions in class. Cubukcu (2007) stated that the fear of negative evaluation is one of the common factors in language learning. Horwitz and Cope (1986) namely fear of negative evaluations coming from students. But these anxious students are able to regulate their feelings and feel comfortable when they speaking in front of their classmates. Young (1990) argues that in his research on students' perspectives on anxiety and speaking in a foreign language, many students reported that they would be more willing to talk if they were not afraid to make mistakes and got negative evaluation in front of their teachers and peers. 
Another factor that causes speaking anxiety is fear of get difficult material in presentation. These results are the same as the findings from Irwanti's (2017) study that participants experienced fear when they did not understand the topic or material they present.

Poor personal experience in public speaking is also one of the factors that cause speaking anxiety as blamed and laughed at by their friends. Geist (in Astrid, 2010) revealed that individual experiences are one of the factors that cause public speaking anxiety, due to lack of experience or the presence of unpleasant experiences felt by someone. This causes a person to tend to have negative thoughts and feelings towards himself and avoid talking in public. In addition, Shabani (2012) also found that the source of anxiety in speaking class was fear of being laughed at by peers.

Speaking anxiety can have positive and negative effects on students' speaking skills. That depends on whether students are able to manage their anxiety or not. This is supported by Griffin and Tyrrell (2007) that students will achieve optimal performance if they can control their anxiety into positive feelings rather than being controlled by the anxiety itself. From the statement, it can be concluded that the effects of anxiety depend on how learners take position in their anxiety. The effects of talking anxiety can be at the academic, cognitive, social and personal level.

The relationship between anxiety and academic achievement is very complex and is proven by Nadeem et al. (2012). From the study, it was shown that anxiety had a very high impact on student academic achievement. The findings show that if one factor increases, the other will decrease. In other words, when anxiety increases, academic performance decreases.

It is also experienced by pre service teachers of STKIP Al Hikmah though they have learned English since they were child. However, they are still anxious as required to do public speaking or do class presentation. This phenomenon is supported by Chowduri (2014) who also claimed that students who speak English faced difficulties when they are required to speak even after learning the language for such a long time. Their fear and anxiety in speaking, and appearing in front of their friends showed that they had dealt with anxiety since they fear to speak. There are two possibilities occured in students suffered from speech anxiety. Speech anxiety can be in the form of facilitative or debilitating anxiety. Phillips \& Croxall (2005) found that debilitating 
anxiety occurred in his research. He concluded that language anxiety clearly affects students' oral performance in language teaching. They become nervous when their teacher calls their names to appear in front of the class. Even when they have prepared the script, they will easily forget what they have to say. Students with high levels of anxiety will face these symptoms because they still cannot control themselves.

Horwitz et al. (1986) identified three varieties or sources of foreign language anxiety. The first variety is communicative apprehension, which arises from the inability to adequately express thoughts and ideas. The second is fear of negative evaluation (FNE) which is defined as apprehension about others' evaluations, avoidance of evaluative situations, and the expectations that others would evaluate one-self negatively. The third source is test anxiety or apprehension over academic evaluation. These three types of anxiety can cause students to postpone language study indefinitely or to quit learning altogether. They are experienced by many language learners and they pose potential problems because they interfere with and restrain learner's ability and ultimately impede their proficiency in the foreign language.

From explanation above, we can conclude that students 'anxiety in learning and speaking English really influences the continuity of students' learning processes in learning English in the classroom.. In accordance with, this research was purposedly carried out to investigate Indonesian pre service teachers' speaking anxiety in EFL classroom

\section{METHOD}

The research design of this study is descriptive qualitative research. This research was conducted at STKIP Al Hikmah Surabaya.The subject of this research is 40 pre service teachers of STKIP Al Hikmah ranged from the first to fourth semester. The instrument used in this research is Horwitz Foreign Language Classroom Anxiety Scale (FLCAS). The result of this research was then descriptively analyzed.

\section{FINDINGS AND DISCUSSION}

As previously mentioned, a number of 40 pre service teachers of STKIP Al Hikmah Surabaya participated in this research by filling out the questionnaire and then returned to researcher to be analyzed. There were four options available in the 
questionnaire namely Strongly Agree (SA) and Agree (A) that latter were combined together to gain a global degree of agreement. The responses 'Disagree' (D) and 'Strongly Disagree' (SD) were also matched to get an overall measure of disagreement. The responses marked with 'undecided' $(\mathrm{N})$ were purposedly dropped because they reveal students' indecisiveness as whether they experienced speaking anxiety or not. The following table shows the percentage of speaking anxiety in EFL classroom experienced by Indonesian pre service teachers.

Table 1. Speaking Anxiety Percentage in EFL Classroom

\begin{tabular}{|c|c|c|c|}
\hline Number of Students & Experienced Anxiety & $\begin{array}{c}\text { Not experienced } \\
\text { Anxiety }\end{array}$ & Total \\
\hline 40 & $50.68 \%$ & $49.32 \%$ & $100 \%$ \\
\hline
\end{tabular}

In addition to, the setudents' responses were also deeply analyzed to reveal the major sources of speaking anxiety experienced by Indonesian pre service teachers in EFL classroom. As a result, there are five major speaking anxiety-affecting sources reported in table 2 as follows:

Table 1. Factors Affecting Speaking Anxiety in EFL Classroom

\begin{tabular}{|c|c|c|}
\hline $\begin{array}{c}\text { Sources of EFL Speaking } \\
\text { Anxiety }\end{array}$ & Number of Items & $\begin{array}{c}\text { Agreement (\%) } \\
\text { (SA+A) }\end{array}$ \\
\hline Fear of interaction & $3,9,11,16,18$ & $25.3 \%$ \\
\hline Fear of peer perception & $5,17,23,31$ & $24.1 \%$ \\
\hline Low self esteem & $1,7,13,14,24,25,26,27,29,30$ & $24.0 \%$ \\
\hline Language proficiency & $2,4,6,10,12,20,21$ & $26.8 \%$ \\
\hline Fear of negative correction & $15,19,33$ & $28.3 \%$ \\
\hline
\end{tabular}

Table 2 above reveals that speaking anxiety experienced by Indonesian pre service teachers in mostly aspects such as fear of interaction, fear of peer perception, low self esteen, language proficiency and fear of negative correction. The highest level of speaking anxiety occured in fear of negative correction. Most of pre service teachers were afraid that the language lecturer was ready to correct every mistake made by the pre service teachers. Moreover, they mostly got upset when they did not understand what the lecturer was correcting. Additionally, they also got nervous when the language lecturer asked questions which they had not prepared in advance. 
In addition, language proficiency and fear of interaction become the the second and third place respectively as the sources or factors affecting speaking anxiety in EFL classroom. Dealing with language proficiency, most pre service teachers were frightened when they did not understand what the lecturer was saying in the foreign language. During language class, they also were thinking about things that have nothing to do with the course. However, they worried about the consequences of failing my foreign language class. In language class, they could get so nervous because they easily forgot things they had known. They also claimed that they would become more confused as they studied for a language test.

Fear of peer perception has become a significant factor affecting speaking anxiety. Most of pre service teachers claimed that the other pre service teachers speak the foreign language better than they do. They were afraid that the other pre service teacher would laugh at them when they were speaking the foreign language. It led them into speaking anxiety.

Interaction also has become one of the major factors affecting speaking anxiety experienced by pre service teacher in EFL classroom. Most pre service teachers trembled when they know that they were going to be called on in language class. As a result, they started to panic when they have to speak without preparation in language class. In other hand, several students still felt anxious even they were well prepared for language class.

Self esteem and confidence could be the most frequent aspects leading to speaking anxiety in EFL classroom. Most pre service teachers never feel quite sure when they were speaking in foreign language class. They also keep thinking that the other students are better at languages than they are. In addition, they would not voluntarily answer in foreign language class because that would be embarrasing for them. The pre service teachers also considered that language class moves so quickly so that they worried about getting left behind. Consequently, they felt more tense and nervous in language class than in my other classes. They also got nervous and confused when they were speaking in language class. Additionally, they gott nervous when they do not understand every word the language teacher says. Likewise, they also felt overwhelmed by the number of rules they have to learn to speak a foreign language. 


\section{CONCLUSION}

The present research was carried out to investigate the nature and sources of foreign language speaking anxiety experienced by pre service teachers of STKIP Al Hikmah Surabaya. Through the use of a modified version of Horwitz et al.'s (1986) Foreign Language Classroom Anxiety Scale, the results of this study demonstrated that many pre service teachers experienced speaking anxiety particularly in EFL classroom like fear of interaction, fear of perception of others, low self-confidence and low selfesteem and many others. On the basis of these results, several implications were proposed to raise foreign language lecturers' awareness about the negative impacts anxiety has on students' ability to speak and the various sources that contribute to it. It is hoped that these implications will encourage the lecturers to identify pre service teachers with a high level of anxiety and create a safe supportive environment so that they feel motivated to actively speak particularly in EFL classroom.

\section{REFERENCES}

Astrid, (2010). The Relationship between Self Efficacy and Public Speaking anxiety in the Students of Psychology Faculty of University Sanata Dharma. Thesis. University Sumatra Utara.

Brown, H. Douglas. (2004). Language Assessment Principles and Classroom Practices. New York : Pearson Education

Chowdury, M.F. (2014). Interpretative in Aiding Our Understanding of the Contemporary Social World.Open Journal of Philosophy, 4, 432-438.

Cubukcu, F. (2007). Foreign Laguage Anxiety.Iranian Journal of Language Studies, 1(2).

Devito, A, J. (1995). The Interpersonal Communication Book (7th ed.). New York: Harper Collins Cllege Publishers.

Griffin, J., \& Tyrrell, I. (2007).How to Master Anxiety. Great Britain: The Bath Press.

Horwitz, E.K., Horwitz, M.B., \& Cope, J. (1986). Foreign language classroom anxiety. The Modern Language Journal, 70, 125-132.

Irwanti, E. (2017). The Reasons Of Studies Reticence in English Education Study Program. An Article.Universitas Tanjungpura Pontianak. 
Jones, R. (2004). Speaking and Listening. London: John Murray Publishers Ltd

Miles , M.B \& Huberman A.M. (1984). Analisis Data Qualitatif. Translated by Tjejep Rohendi Rohidi.1992. Jakarta: Published by Indonesia University.

Nadeem, M., Ali, A., Maqbool, S., Zaidi, S. U. (2012). Impact of Anxiety on the Academic Achievement of Students Having Different Mental Abilities at University level in Bahawalpur (Southern Punjab) Pakistan. International Online Journal of Educational Sciences, 2012, 4 (3), 519-528.

Phillips, R. A., J. R. D. Silk, and J. P. Croxall. (2005). Foraging and provisioning strategies of the light-mantled sooty albatross at South Georgia: competition and co-existence with sympatric pelagic predators. Marine Ecology Progress Series 285:259-270.

Shabani, M. B. (2012). Level and Sources of Language Anxiety Fear of Negative Evaluation among Iranian EFL Learners. ISSN 1799-2591.

Tiara, E. T. M. (2010). Description of Level Anxiety Speaking in front of Class in Tenth Grade and Eleventh Grade in Senior High School Frasiskus Bandar Lampung School Year 2009/2010. Thesis. University Sanata Dharma Yogyakarta.

Toth, Zsuzsa. (2010), Foregn Language Anxiety and the Advance Language Learner, Cambridge Scholars: Cambridge.

Tseng, Shu-Feng. (2012). The Factors Cause Language Anxiety for ESL/EFL Learners in Learning Speaking. Taiwan: Cheng Shiu University.

Williams, K. E., \& Andrade, M. R. (2008). Foreign Language Learning Anxiety in Japanese EFL University Classes: Causes, Coping, and Locus of Control. Electronic Journal of Foreign Language Teaching, 5(2), 181-191.

Young, D. J. (1990). An Investigation of Students' Perspective on Anxiety and Speaking. Foreign Laguage Annals, 23, 539-553. 